\title{
Collaborative Advantage in Public and Social Services: the Case of Poland
}

\author{
Maria Janina Szymankiewicz
}

\section{A B S T R A C T}

Objective: This article seeks to analyse the relationships between the third and the public sector, with a particular focus on relations with local government units (LGUs) on the example of Poland.

Research Design \& Methods: Research methods include literature overview together with the analysis of results of a 2012 focus group interview regarding the model of cooperation between public administration and NGOs, and several free-form interviews performed in 2013 with representatives of social organizations.

Implications \& Recommendations: The tools within the strategic cross-sector collaboration model are helpful in the realization of the strategy of co-operation and collaborative advantage. They ought not to be used, however, in a selective manner or at random, since it is absolutely vital to create a coherent system of co-operation based on the demonstrated rules. The system should also be regularly monitored and continually improved with a long-term collaboration in mind.

Contribution \& Value Added: The article characterises the essence and rules of collaboration between the social and public sectors in Poland, and determines the meaning of the cooperative development of strategy of collaborative advantage. It also presents a useful tool which facilitates the realisation of such a task - a model of strategic cross-sector collaboration.

\begin{tabular}{ll}
\hline Article type: & conceptual paper \\
Keywords: & the third sector; collaboration; public sector; private sector; NGOs; \\
& collaborative advantage
\end{tabular}

JEL codes: H00, L30, L31

Published by Centre for Strategic and International Entrepreneurship - Krakow, Poland

\section{Suggested citation:}

Szymankiewicz, M. J. (2013). Collaborative Advantage in Public and Social Services: the Case of Poland. Entrepreneurial Business and Economics Review, 1(4), 71-81. 


\section{INTRODUCTION}

Social organisations, also called non-governmental organisations (or NGOs), are beginning to play an increasingly important role in Poland in multiple areas of life, which indicates a departure from the historical perception of the economy as being dual-sector, and a transition to the triple-sector model:

- the public sector (governmental), which creates and operates in accordance with the law and may be identified as a state,

- the business or corporate sector (economy, private sector), which functions on the basis of the market and its laws, with 'profit' being the key word,

- the third sector (social, non-governmental), determined by its objectives and values, is where the NGOs - operating on the boundary of the public and private sector - belong.

The third sector, like the other two, is seeking effective methods of management. In this context a strategy of collaboration with the other sectors, developed by social organizations, becomes of great significance. The development and operation of an organisation does not depend exclusively upon the organisation itself, but - to a higher degree - on its relationships with its environment. This is also quite valid in the Polish reality and refers to the cross-sector relations outside the world of business. NGOs do not operate in a void, but function in specific surroundings that include numerous groups of stakeholders. Communications with their surroundings allows them to inform the outer world about the character of their activity, to learn the needs of their stakeholders, to gain support for their actions, to build trust, and, as a result, to realise their goals and objectives in a much more effective manner.

\section{MATERIAL AND METHODS}

The main aim of the article is to analyse the relationships between the third sector and the public sector organisations, with a special focus on relations with local government units (LGUs) in Poland. In order to achieve the aim, following research methods were applied: literature review with the analysis of results of a 2012 focus group interview related to the model of cooperation between public administration and NGOs, as well as a number of free-form interviews carried out with representatives of social organizations in 2013.

This article constitutes an analysis of the relationships between the third and the public sector, particularly concentrating on NGOs' relations with LGUs. In management studies such a cooperation belongs to the newly arising subdiscipline of public management. The growth of importance of The New Public Management (NPM) has contributed to a significant development of the idea of collaboration in the public sector, quite noticeable in Poland after its accession to the EU. The article is also an attempt to characterise the essence and rules of collaboration between the social and public sectors, and to determine the meaning of the cooperative development of collaborative advantage strategy. The article also presents a useful tool which facilitates the realisation of such a task - a model of strategic cross-sector collaboration. As far as the research methods are concerned, the literature of the subject was analyzed, together with the 
results of a 2012 focus group interview regarding a model of cooperation between public administration and NGOs, and several free-form interviews performed in 2013 with representatives of social organizations.

\section{LITERATURE REVIEW}

\section{The Essence of the Third Sector}

The third sector organizations perform numerous important tasks for the benefit of society and, therefore, they are often called social organisations (Kendall, 2011). They constitute a response to the insufficient social services provided by the state, and their main objective is to address the issue of social order. The term third sector has been introduced in the late 70 s of the 20th century. The first who tried to describe this phenomenon was Jacques Delors. He defined it as 'a variation on the theme of the services sector' (Mertens, 1999, p. 501). Both in theory and in practice one may find various often interchangeably used forms of a social organisation, as: the third sector, non-governmental organization (NGO) or non-profit organization. In Poland the operation of NGOs is regulated by the Public Benefit and Volunteer Work Act of 2003, where NGOs are defined as 'not being public finance entities as defined in the provisions on public finance [...], and operating without the purpose of profit gains, legal persons or units without legal personality founded under and in terms of the provisions of the act, including foundations and associations' (Ustawa..., 2003).

Despite its continuous growth, the polish third sector's position is still weaker than the standing of the business (private) and public (governmental) sectors. The main reason may be related to the fact that in the communist era there was no space for authentic social initiatives to the benefit of the general public, since all activity was state controlled $^{1}$. That resulted in the disappearance (atrophy) of the legal form of a foundation. It is, however, worth paying attention to the social sector, since its appropriate functioning translates into the realisation of fundamental liberty and democratic rules while the expansion of its scope facilitates the development of a civil society, including proper collaboration of all three sectors.

\section{The Strategy of Collaborative Advantage in Provision of Public and Social Services}

Each organisation has the ability to collaborate, which enables a more efficient and economical realisation of their objectives, whose single-handed accomplishment would be impossible or would require more expenditure. Following A. Fowler we can say, that NGOs are part of 'open systems' (Fowler, 1997), where the management of relationships is the main area of management. According to Lewis (2003) 'this makes development of NGOs highly dependent on events and resources in their environment, but it also gives NGOs the potential to influence that environment'. Therefore, organisations form alliances with other entities and participate in miscellaneous interactions with elements constituting their environment. The relationships may be competitive, neutral or

\footnotetext{
${ }^{1}$ The backdrop for this talk about the third sector in Poland seems to be similar to the situation in Russia, and every post-socialist country. An interesting development for the third sector in Russia can be found in Hemment (2004).
} 
collaborative. The collaborative relations, which are of interest to us, have a different meaning from the point of view of an organisation. The relationships between enterprises (business organisations) are of a competitive nature, while collaboration takes place when it allows for complementation or even strengthening of their competitiveness. Thus, the collaboration strategy is not an alternative to the strategy of competition. Moreover, it enables achieving sustainable competitive advantage with relation to the competitors outside the coalition (Faulkner \& Bowman, 1996, p. 44).

The logic of collaboration in non-profit, public and social organisations is different. Competition may be justified for the sake of the realisation of public or social objectives, but it is not a prerequisite of their existence. Nevertheless, the mechanism of competition leads to the rise of operational effectiveness, which is crucial in relation to the necessity of effective usage of public funds. What is typical for social and public organisations, however, is the cooperation enabling the increase of their ability to offer services, since the nature of a public organisation involves an obligation to collaborate with other organisations, regardless of their sector of origin. In the case of social organisations, even though cooperation with other organisations is an independent and free-will decision, collaboration is also necessary in practice, to meet their social objectives. The factors that facilitate the collaborative approach are the similarity of operation in the public and social sector, both oriented towards the realization of public and social objectives, and the transparency of operation, openness and democracy, as well as the participation of structurally different social groups.

There is no such similarity between the public and private sector, which makes crossing their boundaries more difficult than the collaboration between the public sector and NGOs. Nevertheless, the practice and theory of public-private partnership (PPP) has been developing very dynamically recently (Zysnarski, 2003; Plawgo \& Zaremba, 2005; Siwińska, 2008; Partnerstwo..., 2013). A public-private partnership is an institution based on the collaboration between a governmental unit and a private entity, regulated by the provisions of a commercial agreement. It means the cooperation of a public organisation with a business one, involving a long-term commitment of private investors into the public sector, following the regulations that facilitate a more effective realisation of public objectives and, at the same time, guaranteeing profits for the enterprise (Zysnarski, 2003, p. 11). The abiding rules and regulations are stipulated by the Public-Private Partnership Act of 28th July 2005 (Ustawa..., 2005) and have been subsequently amended, with the latest amendment as of 1st January 2013.

The relationships between social and public organisations are influenced by the perception of the role of social organisations in public life, which results in the adoption of the following three conceptions (Plawgo \& Zaremba, 2005, pp. 98-99):

- The conception of independence assumes that social organisations (from the third sector) are independent and constitute an opposition to the public sector, because they usually provide different services. In such circumstances public organisations play a minor role in financing social organisations.

- The conception of dependence assumes that social organisations depend on public ones, since they provide social services on behalf of the state, which automatically translates into their submission to the inspection and surveillance by government institutions and self-government bodies. 
- The conception of partnership is based on the assumption (statement) that social organisations are partners and co-operators for public organisations and, in consequence, they ought to have a substantial influence upon the strategy of social policy, particularly on the level of local authorities. This conception becomes the foundation for the development of collaborative advantage.

The character of relationships with the environment, in the case of public and (very many) social non-governmental organisations, is determined by their drive to collaborate with other organisations, which leads to the development of collaborative advantage. The theoretical foundations of collaborative advantage can be traced in relational exchange theory and relational approaches towards organisational strategy, which point to the existence of privileged relationships formed by organisations with their selected partners. Then, competition becomes a mechanism of secondary importance, while concluding free-will contracts and agreements that exceed the boundaries of pure competition becomes the most important issue (Kożuch, 2009, p. 214).

These relationships, called collaboration, provide a lot of opportunities in terms of goals' achievement due to the fact that organisation's own resources and possibilities do not limit it any more. It enables achieving mutual and individual objectives, which without a help of a collaborative partner would not be reachable. In case of a collaboration between public and non-government organisations, the created advantage enables a better solving of social problems. This advantage is called 'collaborative advantage'. In spite of the benefits it provides for both partners, this type of advantage is hardly achievable. The cooperation started by organisations, usually develops very slowly, and in many cases is not successful. Despite the examples of such negative experience it is worth to put efforts in building up long-term relationships with co-operators (Huxham \& Vangen, 2005, pp. 3-4).

A local environment creates particularly favourable conditions for collaboration. The research performed in Poland by Klon/Jawor Association shows that NGOs most closely collaborated with local communities (83\%) and public institutions, since $78 \%$ respondents declared that they maintain contacts with local self-governing bodies, i.e. local government units (LGUs). A similar percentage of organisations (78\%) cooperates with other NGOs (Herbst \& Przewłocka, 2011, pp. 13 and 117).

The basis for the development of collaborative advantage is an existing, distinctive convergence and complementariness of fundamental assumptions made in the public and social sector. Both parties prefer actions taken to the benefit of public interest and common good, and often operate in the same natural environment. Long-term relationships most often turn out to be mutually beneficial, because the aims of co-operating parties are, at least partially, coherent and lead to the satisfaction of local society's needs (Bogacz-Wojtanowska, 2012). Each party also has its own individual advantages. A local government is an important employer in its jurisdiction area, has the right to exercise the power that originates from direct and general elections, and administers the money from the local budget as well as communal assets. Another important aspect is the organisation of its work in accordance with the law regulating the operation of governmental bodies. The advantages of NGOs include their independence and unconventionality of operation, their recognition of social needs, which may not be obvious for the higher levels of authority, lower labour costs due to the commitment of 
volunteers, support from other NGOs (on a national and international scale), as well as the possibility to use various sources of financing. The most important advantage, however, is highly motivated people - volunteers with a strong will 'to make the world a better place' (Limański \& Drabik, 2007, p. 148). Their commitment and devotion enables the realisation of goals that could never be accomplished under any other circumstances.

In recent years the issue of collaboration of NGOs with public organisations has become increasingly important in public policy. After the political and economic transformation of 1989 in Poland - decentralisation trends have become more explicit and the concept of local governance has gained popularity. The concept is mainly based on relationships among different partners, with particular focus on social ones. The collaboration between public and non-governmental organisations, especially on a local scale, reflects the trends concerning the development of a regional public policy by numerous committed and motivated social players (Bogacz-Wojtanowska, 2011a, p. 13). Social-public cooperation is also strengthened by the development and implementation of modern models of public management. As government administration facilitated the dominant role of public organisations, the new public management supports various forms of cross-sector collaboration, e.g. contracting services (Kożuch, 2006, p. 27). The concept of public governance assumes the development of a network of public connections including the organisations from the third sector. Similarly, the conception of public service places emphasis on the co-existence of multiple entities that form coalitions in order to meet the determined needs of specific groups of citizens (Bogacz-Wojtanowska, 2011a, p. 16). To strengthen these tendencies, since 2008 the 'Partnering Local Government' ranking has been carried out, which summarises the intensity of collaboration between local governmental administration and NGOs. The ranking is created on the basis of an annual report 'Monitoring of collaboration between NGOs and self-governing units', which is a joint enterprise of Klon/Jawor Association and the Department of Public Benefit at the Ministry of Labour and Social Policy.

\section{Conditions of Cross-Sector Collaboration between NGOs and LGUs}

The collaboration of NGOs and LGUs is referred to in the Preamble to the Constitution of the Republic of Poland which was adopted on 2nd April 1997 by the National Assembly. The text contains a reference to the collaboration of authorities and community dialogue in accordance with the principle of subsidiarity which strengthens the authorisations of citizens and their communities. The cooperation of LGUs with NGOs took on a new light after 2003 when the Public Benefit and Volunteer Work Act was passed (Ustawa..., 2003). The Act regulates the rules and regulations of collaboration for both parties (Polish Journal of Law, No. 96, Item 873, with amendments). The amendment act of 22nd January 2010 introduced the amendments which significantly facilitate the conditions of collaboration. The monitoring of the implementation of the Public Benefit and Volunteer Work Act has shown, however, numerous discrepancies in the process of the realisation of such collaborations (Bogacz-Wojtanowska, 2011b, p. 79). The commonly reported issues resulting mainly from the dominant position of public authorities include (Swianewicz, 2008): 
- insufficient resources available to non-public partners,

- weakness of citizen ties,

- low level of mutual trust, which hinders collaboration,

- traditional, hierarchical administrative structure.

Despite these obstacles, in Poland there are numerous satisfactory or even exemplary collaboration of local governmental bodies with NGOs, such as NGO Centres (NGOCs) with the longest operating one in Gdynia. Therefore, it is worth paying attention to the postulates on the regulations (conditions) of successful collaboration expressed by both parties, as well as the suggestions on its standardisation. The methods of operation of local authorities and NGOs complement each other and, thus, it is advisable to use them for the benefit of local communities. The research performed in 2010 by the Institute of Public Affairs shows the main postulates regarding attitudes, relationships and partnership, issued by the representatives of both public administration and NGOs (Table 1).

Table 1. The postulates regarding attitudes, relationships and partnership as conditions of successful collaboration

\begin{tabular}{|c|c|c|c|}
\hline \multirow{2}{*}{ Respondents } & \multicolumn{3}{|c|}{ The features of cross-sector collaboration indicated by the respondents } \\
\hline & The right attitude & Good relationships & Partnership \\
\hline $\begin{array}{l}\text { Representatives } \\
\text { of NGOs }\end{array}$ & $\begin{array}{ll}\text { o } & \text { transparent character of } \\
\text { partner's operation (public } \\
\text { administration), } \\
\text { o tolerance for the } \\
\text { spontaneous nature of an } \\
\text { organisation, } \\
\text { o openness of administration } \\
\text { to the needs of the third } \\
\text { sector, } \\
\text { o mutual understanding of } \\
\text { needs, } \\
\text { o readiness of administration } \\
\text { to consider the reported } \\
\text { problems. }\end{array}$ & \begin{tabular}{|l} 
avoidance of relationships \\
based on submission and \\
dominance (by both \\
parties), \\
o equality, \\
o communicativeness, \\
o providing assistance for \\
NGOs, but without doing \\
their job instead of them, \\
o avoidance of formality, \\
o avoidance of circumstances \\
leading to conflicts among \\
NGOs.
\end{tabular} & $\begin{array}{ll}\text { o } & \text { co-initiating actions, } \\
\text { o } & \text { avoidance of } \\
& \text { 'contractor-client' } \\
& \text { type of relationships, } \\
\text { o } & \text { respect for the } \\
& \text { autonomy of NGOs, } \\
\text { o } & \text { esteem of the } \\
\text { organisations, } \\
\text { o } \quad \text { mutual } \\
\text { complementation in } \\
\text { everyday operation, } \\
\text { o 'diplomacy', } \\
\text { o compromise. }\end{array}$ \\
\hline $\begin{array}{l}\text { Representatives } \\
\text { of public } \\
\text { administration }\end{array}$ & $\begin{array}{l}\text { the need to perceive NGOs } \\
\text { as competent partners, } \\
\text { o comprehension of the } \\
\text { specificity of partner's } \\
\text { operation (NGO), } \\
\text { o NGOs' understanding that } \\
\text { administration is not always } \\
\text { aware of all problems and } \\
\text { needs, } \\
\text { openness in contacts, } \\
\text { o personal etiquette, } \\
\text { o expressing real interest in } \\
\text { the operation of } \\
\text { organisations, } \\
\text { o organisations demonstrating } \\
\text { the will to collaborate with } \\
\text { administration. }\end{array}$ & $\begin{array}{ll}\text { o } & \text { equality, } \\
\text { o } & \text { communicativeness, } \\
\text { o } & \text { good will of both parties, } \\
\text { o } & \text { mutual understanding. }\end{array}$ & \begin{tabular}{|ll} 
o & ability to \\
compromise, \\
o patience.
\end{tabular} \\
\hline
\end{tabular}

Source: adapted from (Bogacz-Wojtanowska et al., 2010). 
After the analysis of Table 1 containing the postulates of good collaboration it can be concluded that the basis of the process of their development is the implementation of particular rules, among which the most vital seem to be (Romanowska \& Trocki, 2002, pp. 85-86):

- the obedience of ethical criteria of cooperation, e.g. affirmation of certain conditions, keeping to initially agreed stipulations, strict realisation of the agreed quality conditions, terms of payment, delivery conditions, and general, mutual care for partners' benefits,

- the pursuit to increase organisational effectiveness and economic feasibility,

- respect for the customary norms based on the community of objectives and interests, mutual respect.

\section{RESULTS AND DISCUSSION}

\section{An Attempt at Standardisation - a Polish Model of Collaboration}

Since one can still observe cases of dysfunctional relationships between public administration and the third sector, and negative examples of a visible lack of cooperation, the discourse on the improvement and development of this collaboration appears to involve the issue of its standardisation. Standardisation is understood as 'a developed, agreed and accepted, common approach to the collaboration between LGUs and NGOs, prepared in accordance with the law, and the unification of procedures, the acceptance of best practices, the formation of common language of description and modelling, as well as the development and upgrading of common databases' (Batko, 2009 , p. 129). This type of standardisation requires the determination of rules and conditions of collaboration. Such an attempt is the Model of Collaboration between Public Administration and NGOs, hereinafter referred to as the Model. It focuses on the most vital forms of collaboration between non-governmental organisations and local authorities, was prepared in full compliance with the appropriate regulations of law, and serves the needs of both parties - NGOs and LGUs (the latter understood as legislative and executive bodies with their subordinate organisational units). The development of a model of collaboration became an important issue since the scope of cooperation between NGOs and LGUs seemed to have been insufficient. The research performed among public organisations directly before Poland's accession to the EU (Kożuch, 2007, pp. 83-84) showed that cooperative initiatives were taken mainly as the result of legal requirements and were of a limited scope since they were generally restricted to informing other organisations about their own strategic plans and running consultations in certain areas. It was very rare, however, for organisations to get involved in the preparation of local documentation and the decision-making process. The changes became noticeable in 2003 after the passing of the Public Benefit and Volunteer Work Act, and with the increasing accessibility to European funds (Kożuch, 2007, pp. 83-84).

The Model developed between 2010 and 2012 is well grounded in the existing legal framework, especially in the Public Benefit and Volunteer Work Act. It is worth noticing, however, that the main focus is placed on the culture of collaboration, defined as the phenomenon exceeding the realm of the abiding law. Part of the issues within the Model, e.g. local partnerships, are not the result of the law, but the culture of 
cooperation. The Model recommends basing the collaboration on three levels (Table 2) and following the rules and regulations it contains.

The main purpose of the Model is to present an optimum and - at the same time - a simplified state of collaboration. At present both the authors of the Model and its propagators face the challenge of preventing the Model from being perceived as another universal and, thus, useless tool. The popularisation of its stipulations and constituents seems to be a minor issue at the moment.

Table 2. Three surfaces of collaboration between LGUs and NGOs

\begin{tabular}{|l|l|l|}
\hline \multicolumn{2}{|c|}{ LEVEL I } & \multicolumn{1}{c|}{ LEVEL III } \\
\hline $\begin{array}{l}\text { The collaboration of LGUs and } \\
\text { NGOs in the process of } \\
\text { development of public policies } \\
=\text { systemic and regulatory actions } \\
\text { taken in order to solve the most } \\
\text { serious problems of the residents } \\
\text { of local communities. }\end{array}$ & $\begin{array}{l}\text { Thes in the process of the } \\
\text { realisation of public objectives } \\
\text { administration in accordance } \\
\text { with the law regulating their } \\
\text { terms of public reference. }\end{array}$ & $\begin{array}{l}\text { Collaborative infrastructure (the } \\
\text { whole of locally developed } \\
\text { factors that influence the } \\
\text { operation of NGOs and the } \\
\text { gollaboration between the self- } \\
\text { sector) and the creation of good } \\
\text { conditions for social activity. }\end{array}$ \\
\hline \multicolumn{3}{|c|}{ TERMS OF COLLABORATION: } \\
\hline subsidiarity, independence of partnership, effectiveness of standardisation, fair competition, transparency, \\
and equality of opportunities.
\end{tabular}

Source: own elaboration based on (Departament..., 2013).

The Model should serve as a framework in the process of the development of locally applicable standards of cross-sector collaboration (Rymsza \& Dudkiewicz, 2012, pp. 5-6). Even though the Model does not include all the aspects the recipients may consider important for a successful collaboration, it contains all its crucial levels, while the summary recommends such a realization of collaborative strategy that it promotes the development of local communities.

\section{CONCLUSIONS}

The special character of polish public and social organisations, and the certain similarity of their operation (common social and public objectives), facilitates a collaborative attitude. This is a positive phenomenon since there is a need for partnership to solve the most serious social issues and for the expansion of social resources through the engagement of large groups of citizens in the processes of development of both local communities and the country as a whole.

The guidelines and tools within the Model are helpful in the realization of the strategy of co-operation and collaborative advantage. They ought not to be used, however, in a selective manner or at random, since it is absolutely vital to create a coherent system of co-operation based on the demonstrated rules. The system should also be regularly monitored and continually improved with a long-term collaboration in mind.

The development of collaborative advantage by means of the rules specified in the Model requires the continuation of evolution from the model of representative democracy, where all local activity is centralised around the elected representatives and local administration, to the model of participatory democracy. The rationale for such 
an evolution is the observation that a single-handed execution of authority is becoming less effective and it is highly advisable to invite various social and economic players, including NGOs, to share the responsibility. This means the skilful use of collaborative advantage in the realisation of social objectives, and a change in the way the power is executed, to give the key role to the strategy of co-operation, the development of collaborative ties and the rule of partnership.

\section{REFERENCES}

Batko, B. (2009). Standaryzacja procesów jako podstawa doskonalenia administracji publicznej. In K. Lisiecka \& T. Papaj (Eds.), Kierunki doskonalenia usług świadczonych przez administrację publicznq (pp. 129-142). Katowice: Śląskie Centrum Społeczeństwa Informacyjnego.

Bogacz-Wojtanowska, E., Dudkiewicz, M., Górniak, K., Makowski, G., \& Stokowska, A. (2010). Raport czqstkowy na temat współpracy międzysektorowej (na podstawie badań jakościowych). Warszawa: Instytut Spraw Publicznych.

Bogacz-Wojtanowska, E. (2011a). Współdziałanie organizacji pozarzqqdowych i publicznych, Kraków: Monografie i Studia Instytutu Spraw Publicznych Uniwersytetu Jagiellońskiego w Krakowie.

Bogacz-Wojtanowska, E. (2011b). Zarządzanie procesem współpracy jednostek samorządu terytorialnego i organizacji pozarządowych. Trzeci Sektor, numer specjalny, 1, 79-87.

Bogacz-Wojtanowska, M. (2012). Motywy podejmowania współpracy przez organizacje pozarządowe. Trzeci Sektor, 28, 27-37.

Czakon, W. (2007). Dynamika więzi międzyorganizacyjnych. Katowice: Wydawnictwo Uniwersytetu Ekonomicznego w Katowicach.

Departament Pożytku Publicznego (2013). Model współpracy administracji publicznej i organizacji pozarzqdowych. Retrieved on December 15, 2013 from http://www.pokl541.pozytek.gov.pl/ files/Model/Produkty/model_wspolpracy.pdf

Faulkner, D., \& Bowman, C. (1996). Strategie konkurencji. Warszawa: Gebethner \& S-ka.

Fowler, A. (1997). Striking a Balance: A Guide to Enhancing the Effectiveness of NGOs in International Development. London: Earthscan.

Kendall, J. (Ed.). (2011). Handbook on Third Sector Policy in Europe: Multi-level Processes and Organized Civil Society. Cheltenham: Edward Elgar Publishing.

Hemment, J. (2004). The riddle of the third sector: civil society, international aid, and NGOs in Russia. Anthropological Quarterly, 77(2), 215-241.

Herbst, J., \& Przewłocka, J. (2011). Podstawowe fakty o organizacjach pozarzqdowych. Raport z badania 2010. Warszawa: Stowarzyszenie Klon/Jawor.

Huxham, C., \& Vangen, S. (2005). Managing to Collaborate. The Theory and Practice of Collaborative Advantage. London: Routledge.

Kożuch, B. (Ed.). (2006). Problemy zarzqdzania organizacjami publicznymi. Kraków: Fundacja Współczesne Zarządzanie, Instytut Spraw Publicznych UJ.

Kożuch, B. (2007). Zmiany organizacyjne w powiatowych urzędach pracy. Struktury i strategie. Kraków: Wydawnictwo Uniwersytetu Jagiellońskiego.

Kożuch, B. (2009). Nauka o organizacji. Warszawa: CeDeWu.

Lewis, D. (2003). Theorizing the organization and management of non-governmental development organizations. Towards a composite approach. Public Management Review, 5(3), 325-344.

Limański, A., \& Drabik, I. (2007). Marketing w organizacjach non-profit. Warszawa: Difin. 
Mertens, S. (1999). Nonprofit organizations and social economy: two ways of understanding the third sector. Annals of Public and Cooperative Economics, 70(3), 501-520.

Partnerstwo publiczno-prawne w ramach funduszy europejskich 2007 - 2013. (2013). Platforma Partnerstwa Publiczno-Prawnego. Retrieved on December 15, 2013 from http://www.ppp.gov.pl

Plawgo, B., \& Zaremba, W. (Eds.). (2005). Partnerskie współdziałanie w sektorze publicznym i prywatnym. Białystok: Fundacja Współczesne Zarządzanie.

Romanowska, M., \& Trocki, M. (2002). Przedsiębiorstwo partnerskie. Warszawa: Difin.

Rymsza, M., \& Dudkiewicz, M. (2012). Współpraca międzysektorowa w Polsce. Jak ją modelować, jak standaryzować, jak mierzyć jej jakość?. Trzeci Sektor, numer specjalny, 2, 2-7.

Siwińska, J. (2008). Partnerstwo publiczno-prawne. Warszawa: CeDeWu.

Swianiewicz, P. (2008). Partnerska polityka publiczna na poziomie lokalnym. Dialog, 4.

Ustawa o działalności pożytku publicznego i o wolontariacie (2003). Ustawa z dnia 24 kwietnia 2003 r. Dz.U. z 2010 r., Nr 234, poz. 1536 z późn. zm.

Ustawa o partnerstwie publiczno-prywatnym (2005). Ustawa z dnia 28 lipca 2005 r. Dz. U. Nr 169 poz. 1420.

Zysnarski, J. (2003). Partnerstwo publiczno-prywatne. Gdańsk: Teoria i praktyka, ODDK.

\section{Author}

\section{Maria Janina Szymankiewicz}

Master of Management Sciences, Assistant in the Department of Management at University of Lodz (Poland). Research interests: problems of the third sector, NGOs relationship with the environment, social aspects of the functioning of NGOs, the organization and methodology of modern management methods.

\section{Correspondence to:}

Mgr Maria J. Szymankiewicz

University of Lodz

Faculty of Management

Matejki 22/26, 90-237 Łódź, Poland

maria.szymankiewicz@uni.lodz.pl

Published by Centre for Strategic and International Entrepreneurship - Krakow, Poland 
